\title{
Identifikasi Aksi Gen Epistasis pada Toleransi Kedelai terhadap Cekaman Aluminium
}

\section{Identification of Epistatic Genes Action Controlling Soybean Tolerance to Aluminum Toxicity}

\author{
Arvita Netti Sihaloho $^{1,2}$, Trikoesoemaningtyas ${ }^{3 *}$, Didy Sopandie $^{3}$, dan Desta Wirnas ${ }^{3}$ \\ ${ }^{1}$ Program Studi Pemuliaan dan Bioteknologi Tanaman, Sekolah Pascasarjana, Institut Pertanian Bogor \\ ${ }^{2}$ Jurusan Agroteknologi, Fakultas Pertanian, Universitas Sisingamangaraja XII Tapanuli \\ Jl. Silangit No. 9 Tapanuli Utara, Sumatera Utara, Indonesia \\ ${ }^{3}$ Departemen Agronomi dan Hortikultura, Fakultas Pertanian, Institut Pertanian Bogor \\ (Bogor Agricultural University), Jl. Meranti, Kampus IPB Darmaga, Bogor 16680, Indonesia
}

Diterima 14 Mei 2014/Disetujui 24 September 2014

\begin{abstract}
The efectiveness of selection depends on the gene action cotrolling the character. The presence of epistatic gene action will delay the genetic gain in self pollinated crops like soybean. The objective of this research was to obtain information on genetic control of soybean tolerance to aluminum toxicity on nutrient culture. This research was conducted at green house of the University Farm IPB Cikabayan, Bogor, from April to June 2013. This research used 120 seedlings of F2 population generated from crossing between Argomulyo (Al-sensitive) with Tanggamus (Al-tolerant). Seedlings were grown in nutrient culture for 14 days with Al concentration of $1.5 \mathrm{mM}$ and $\mathrm{pH}$ 4.0, to observe the vegetative growth under aluminum stress condition. The result showed that mean of roots length, shoot length, shoot to root ratio, wet and dry weight of root and shoot exceeded both parents mean value with moderate to high heritability. All observed characters had continue distribution pattern, and controlled by many genes. Duplicate epistasis additive gene action controlled only root length while other characters were controlled by complementary epistasis gene action.
\end{abstract}

Keywords: gene action, heritability, nutrient culture, selection, tocixity

\section{ABSTRAK}

Efektivitas seleksi sangat tergantung dari aksi gen yang mengendalikan karakter seleksi. Aksi gen epistatis akan menghambat kemajuan seleksi pda tanaman menyerbuk sendiri seperti kekdelai. Tujuan penelitian ini adalah menduga aksi gen dari karakter pertumbuhan kedelai pada cekaman aluminium di kultur hara, dan menduga apakah karakter pertumbuhan tersebut dikendalikan oleh aksi gen aditif atau oleh aksi gen epistasis.Percobaan dilaksanakan di rumah kaca Kebun Percobaan University Farm IPB di Cikabayan, Bogor mulai bulan April sampai dengan Juni 2013. Penelitian ini menggunakan 120 bibit dari populasi generasi F2 hasil persilangan Argomulyo x Tanggamus. Bibit ditumbuhkan selama 14 hari di kultur hara dengan konsentrasi Al $1.5 \mathrm{mM}$ dan pH 4.0, untuk melihat karakter pertumbuhan vegetatif pada keadaan cekaman aluminium. Hasil penelitian menunjukkan bahwa karakter panjang akar, panjang tajuk, nisbah panjang tajuk per akar, bobot basah akar, bobot basah tajuk, bobot kering akar, dan bobot kering tajuk mempunyai nilai tengah yang melebihi kedua tetuanya dengan nilai heritabilitas dari sedang hingga tinggi. Aksi gen aditif epistasis duplikat hanya terjadi pada karakter panjang akar sedangkan karakter panjang tajuk, nisbah panjang tajuk akar, bobot basah akar, bobot basah tajuk, bobot kering akar, dan bobot kering tajuk diatur oleh aksi gen epistasis komplementer. Semua karakter yang diamati memiliki pola sebaran yang bersifat kontinu dan dikendalikan oleh banyak gen.

Kata kunci: aksi gen, heritabilitas, keracunan, kultur hara, seleksi

\section{PENDAHULUAN}

Kedelai merupakan komoditi pangan strategis di Indonesia yang kebutuhannya terus meningkat sejalan pertumbuhan jumlah penduduk. Salah satu usaha untuk meningkatkan produksi kedelai nasional adalah memperluas

\footnotetext{
* Penulis untuk korespondensi. e-mail: trikadytia@gmail.com
}

areal tanam dengan memanfaatkan lahan-lahan kering yang potensinya sangat besar. Menurut Mulyani et al. (2011), luas lahan kering di Indonesia mencapai 148 juta hektar dan diperkirakan 102.8 juta hektar di antaranya berupa tanah masam.

Kendala budidaya kedelai di tanah masam adalah produktivitas yang rendah. Hal ini disebabkan oleh kesuburan tanah yang rendah karena tanah masam ditandai oleh $\mathrm{pH}$ rendah dan kelarutan Aluminium (Al) yang tinggi. 
Kelarutan Al yang tinggi menyebabkan Al menjadi racun bagi tanaman serta pengikatan unsur hara yang diperlukan oleh tanaman seperti unsur fosfor. Gejala keracunan yang dapat diamati pada tanaman adalah gangguan pertumbuhan akar sehingga penyerapan air dan hara yang dibutuhkan tanaman ikut terganggu (Caniato et al., 2007; Ojo dan Ayuba, 2012).

Pendekatan budidaya yang dapat dilakukan untuk mendapatkan produktivitas yang optimal di tanah masam adalah dengan menanam varietas kedelai toleran terhadap cekaman Al. Deptan (2012) telah melepas 74 varietas, beberapa di antaranya toleran terhadap tanah masam seperti Sibayak, Ratai, Nanti, dan Tanggamus. Umumnya varietas toleran tanah masam yang telah dilepas tersebut mempunyai biji ukuran kecil. Adie dan Krisnawati (2007) melakukan pengelompokan biji kedelai berdasarkan ukuran biji, diketahui bahwa varietas Sibayak, Ratai, Nanti, dan Tanggamus termasuk kelompok berbiji kecil $(<10$ g per 100 biji) .

Saat ini konsumen lebih suka terhadap kedelai berbiji besar. Oleh karena itu, perlu dilakukan pengembangan varietas kedelai berbiji besar untuk kesesuaian budidaya di tanah masam. Keragaman genetik kedelai untuk sifat berbiji besar dan toleran aluminium masih relatif rendah sehingga perlu dilakukan persilangan antara varietas toleran tanah masam (Tanggamus) (Deptan, 2012) dengan varietas peka tanah masam berbiji besar ( $\geq 14 \mathrm{~g}$ per 100 biji), yaitu Argomulyo (Deptan, 2012) untuk memperoleh galur yang toleran tanah masam berbiji besar.

Keragaman genetik terdiri atas ragam genetik aditif, dominan, dan epistasis. Ragam genetik aditif adalah ragam genetik yang menyebabkan terjadinya kesamaan sifat di antara tetua dan turunannya. Fenotipe pada aksi gen aditif disebabkan penjumlahan dari masing-masing alel tanpa interaksi dengan alel lain (interaksi alelik atau non alelik), sedangkan pada aksi gen epistasis, fenotipe ditentukan oleh interaksi alel-alel dari lokus yang berbeda (Roy, 2000)

Toleransi kedelai terhadap tanah masam dikendalikan oleh aksi gen aditif yang juga dipengaruhi aksi gen epistasis. Kuswantoro et al. (2011) menyatakan bahwa pewarisan sifat jumlah polong kedelai di tanah masam dikendalikan oleh aksi gen epistasis. Menurut Phillips (2008) aksi gen epistasis berperan penting dalam adaptasi tanaman terhadap cekaman abiotik seperti cekaman aluminium.

Penelitian bertujuan untuk menduga aksi gen dari karakter pertumbuhan kedelai pada cekaman aluminium di kultur hara dan menduga apakah karakter pertumbuhan tersebut dikendalikan oleh aksi gen aditif atau oleh aksi gen epistasis.

\section{BAHAN DAN METODE}

Percobaan dilaksanakan di rumah kaca Kebun Percobaan Cikabayan IPB, Bogor, pada bulan April sampai dengan Juni 2013. Bahan genetik yang digunakan adalah 120 tanaman yang diperoleh dari populasi $\mathrm{F}_{2}$ hasil persilangan Argomulyo x Tanggamus serta kedua tetua masing-masing berjumlah 20 tanaman.

Media kultur yang digunakan adalah larutan Ohki (1987) dengan komposisi hara lengkap sebagai berikut 1.5
$\mathrm{mM} \mathrm{Ca}\left(\mathrm{NO}_{3}\right)_{2} .4 \mathrm{H}_{2} 0 ; 1.0 \mathrm{mM} \mathrm{NH}_{4} \mathrm{NO}_{3} ; 1.0 \mathrm{mM} \mathrm{KCl} ; 0.4$ $\mathrm{mM} \mathrm{MgSO}_{4} .7 \mathrm{H}_{2} 0 ; 1.0 \mathrm{mM} \mathrm{KH}_{2} \mathrm{PO}_{4}, 0.50 \mathrm{ppm} \mathrm{MnSO}_{4} \mathrm{H}_{2} \mathrm{O}$; $0.02 \mathrm{ppm} \mathrm{CUSO} \mathrm{CH}_{2} ; 0.05 \mathrm{ppm} \mathrm{ZnSO}_{4} .7 \mathrm{H}_{2} 0 ; 0.50 \mathrm{ppm}$ $\mathrm{H}_{3} \mathrm{BO}_{3} ; 0.01 \mathrm{ppm} \mathrm{NH} \mathrm{Mo}_{7} \mathrm{O}_{24} .4 \mathrm{H}_{2} 0 ; 0.068 \mathrm{mM} \mathrm{Fe}\left(\mathrm{C}_{6} \mathrm{H}_{7} \mathrm{O}_{7}\right)$, $\mathrm{pH}$ 4.0. Kondisi tercekam Al dibuat dengan menambahkan Al ke dalam kultur hara sampai media memiliki konsentrasi Al sebesar 1.50 mM (Supijatno et al., 1995).

Benih kedelai dikecambahkan terlebih dahulu pada media sekam bakar steril lembab. Setelah kecambah memiliki dua lembar daun trifoliat (stadia $\mathrm{V}_{2}$ ) dengan panjang akar yang seragam, kecambah dibalut dengan gabus busa lunak kemudian dimasukkan ke lubang yang dibuat pada styrofoam dan diletakkan dalam pot berisi larutan hara sebanyak $2 \mathrm{~L} \mathrm{pot}^{-1}$. Pengamatan dilakukan terhadap panjang akar, panjang tajuk, nisbah panjang tajuk per akar, bobot basah akar dan tajuk, serta bobot kering akar dan tajuk yang dikeringkan dengan oven pada suhu $60{ }^{\circ} \mathrm{C}$ selama 2 hari. Semua pengamatan dilakukan pada hari ke 14 .

Analisis data dilakukan dengan menghitung rata-rata dan dilakukan uji-t untuk setiap karakter yang diamati pada masingmasing populasi, serta dilanjutkan dengan pendugaan aksi gen yang mengendalikan karakter yang diamati. Penentuan aksi gen dan banyak gen pengendali sifat dilakukan berdasarkan analisis sebaran $\mathrm{F}_{2}$ dengan melihat nilai skewness dan kurtosis (Roy, 2000). Komponen ragam dan heritabilitas diestimasi menggunakan persamaan sebagai berikut:

$$
\operatorname{Ragam}(\mathrm{V})=\sum_{\frac{i=1}{n}(x i-\mu)^{2}}^{n-1}
$$

Ragam fenotipe $\left(\mathrm{V}_{\mathrm{p}}\right)=\mathrm{V}_{\mathrm{F} 2}$

Ragam lingkungan $\left(\mathrm{V}_{\mathrm{E}}\right)=\left(\mathrm{V}_{\mathrm{P} 1}+\mathrm{V}_{\mathrm{P} 2}+\mathrm{V}_{\mathrm{F} 1}\right) / 3$

Ragam genotipe $\left(\mathrm{V}_{\mathrm{G}}\right)=\mathrm{V}_{\mathrm{F} 2}-\mathrm{V}_{\mathrm{E}}$ Heritabilitas arti luas $\left(\mathrm{h}^{2}{ }_{\mathrm{bs}}\right)=\left(\mathrm{V}_{\mathrm{G}} / \mathrm{V}_{\mathrm{P}}\right) \times 100 \%$.

Nilai heritabilitas dikategorikan tinggi bila $\mathrm{h}_{\mathrm{bs}}^{2}>50 \%$, sedang bila $\mathrm{h}^{2}$ bs terletak antara $20-50 \%$ dan rendah bila $\mathrm{h}^{2}{ }_{\text {bs }}$ $<20 \%$ (Mangoendidjojo, 2003).

\section{HASIL DAN PEMBAHASAN}

Hasil penelitian di kultur hara menunjukkan bahwa varietas Tanggamus memiliki akar lebih panjang, bobot basah tajuk, dan nisbah panjang tajuk/akar lebih tinggi dan berbeda nyata dibandingkan dengan varietas Argomulyo pada kondisi tercekam aluminium. Menurut Arsyad et al. (2007) dan Deptan (2012), Tanggamus merupakan varietas yang direkomendasikan untuk budidaya di tanah masam sementara Argomulyo biasa ditanam di sawah setelah padi (Ginting et al., 2009). Hal ini sesuai dengan hasil pengamatan bahwa Tanggamus memiliki panjang akar, 30\% lebih panjang dari Argomulyo (Tabel 1).

Kemampuan mempunyai akar lebih panjang diduga menentukan tingkat toleransi varietas Tanggamus terhadap cekaman Al karena tanaman yang toleran terhadap tanah masam adalah tanaman yang pertumbuhan akarnya tidak terganggu dalam keadaan tercekam aluminium (Maron et al., 2008; Silva et al., 2012). Tidak terdapat perbedaan antara Tanggamus dengan Argomulyo untuk karakter bobot 
Tabel 1. Nilai rata-rata karakter akar tetua Argomulyo (P1), Tanggamus (P2), dan populasi F2 pada cekaman aluminium di kultur hara

\begin{tabular}{lcccc}
\hline Karakter & Argomulyo & Tanggamus & Nilai P & Populasi F2 \\
\hline Panjang akar $(\mathrm{cm})$ & $24.06 \pm 4.16$ & $33.26 \pm 8.33$ & $0.00^{*}$ & $33.28 \pm 7.64$ \\
Panjang tajuk $(\mathrm{cm})$ & $63.50 \pm 9.22$ & $50.38 \pm 14.08$ & $0.00^{*}$ & $37.80 \pm 13.90$ \\
Bobot kering akar $(\mathrm{g})$ & $0.09 \pm 0.10$ & $0.16 \pm 0.2$ & $0.16^{\text {tn }}$ & $0.86 \pm 0.60$ \\
Bobot kering tajuk $(\mathrm{g})$ & $1.81 \pm 0.44$ & $2.20 \pm 0.53$ & $0.02^{*}$ & $2.94 \pm 1.04$ \\
Bobot basah akar $(\mathrm{g})$ & $0.04 \pm 0.01$ & $0.05 \pm 0.02$ & $0.09^{\text {tn }}$ & $0.06 \pm 0.03$ \\
Bobot basah tajuk (g) & $0.36 \pm 0.09$ & $0.40 \pm 0.10$ & $0.18^{\text {tn }}$ & $0.42 \pm 0.14$ \\
Nisbah panjang tajuk/akar & $3.00 \pm 0.90$ & $1.51 \pm 0.43$ & $0.00^{*}$ & $1.20 \pm 0.48$ \\
\hline
\end{tabular}

Keterangan: * = berbeda nyata pada taraf 5\% berdasarkan uji-t antara tetua Argomulyo dan Tanggamus; $\pm=$ nilai SE

basah akar, bobot kering akar, dan bobot kering tajuk pada pengamatan 14 hari. Pengaruh aluminium terlihat hanya pada panjang akar sehingga karakter ini dapat digunakan sebagai penanda untuk genotipe toleran secara cepat.

Hasil pengamatan pada populasi F2 menunjukkan bahwa populasi F2 memiliki rata-rata panjang akar, berat kering akar, dan berat kering tajuk lebih baik dari rata-rata kedua tetua, dan terdapat sekitar 6 individu F2 merupakan segregan trangresif. Segregan transgresif terjadi disebabkan adanya efek dominan dan aditif. Jika efek aditif yang terjadi maka akan terfiksasi dan diwariskan pada generasi lanjut.

Gambar 1, 2, 3 dan 4 menunjukkan bahwa semua karakter yang diamati memiliki pola sebaran bersifat kontinu, yang berarti karakter agronomi kedelai pada kondisi tercekam Al dikendalikan banyak gen. Semua karakter yang diamati memiliki pola sebaran bersifat kontinu, yang menunjukkan bahwa karakter agronomi kedelai pada kondisi tercekam Al dikendalikan banyak gen. Semua karakter pada populasi F2
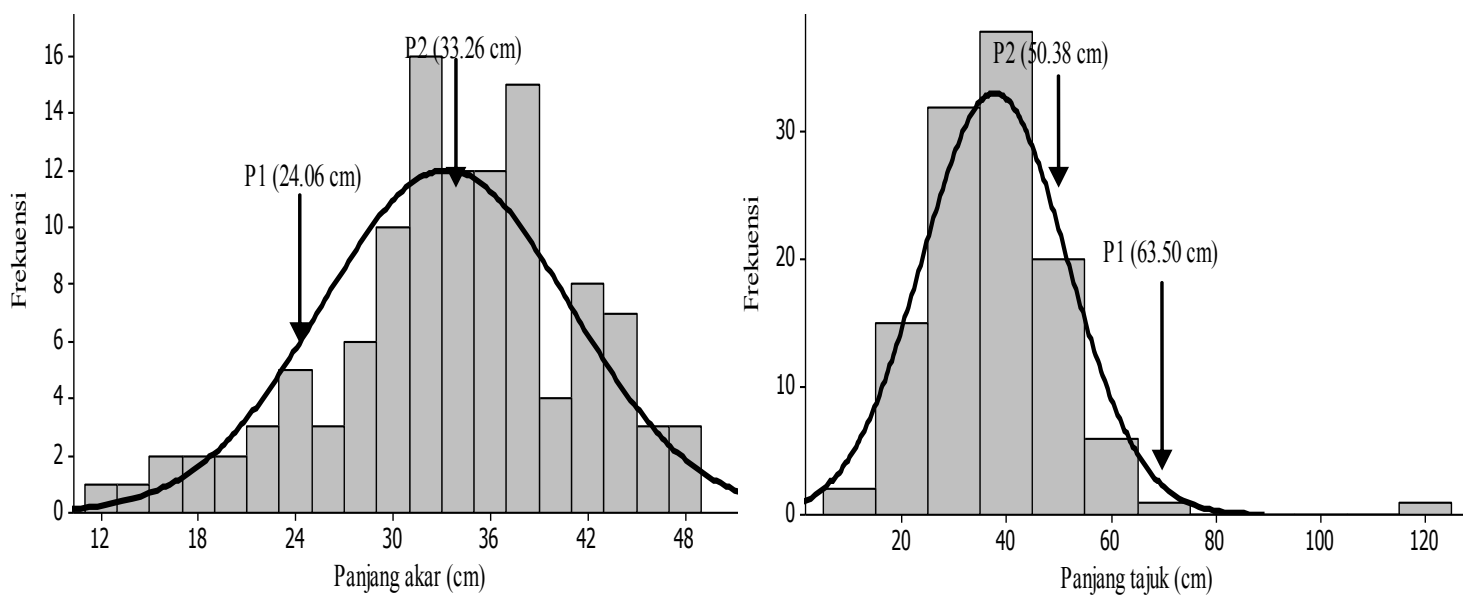

Gambar 1. Sebaran panjang akar dan panjang tajuk populasi F2 tercekam aluminium pada stadia bibit (14 hari) di kultur hara
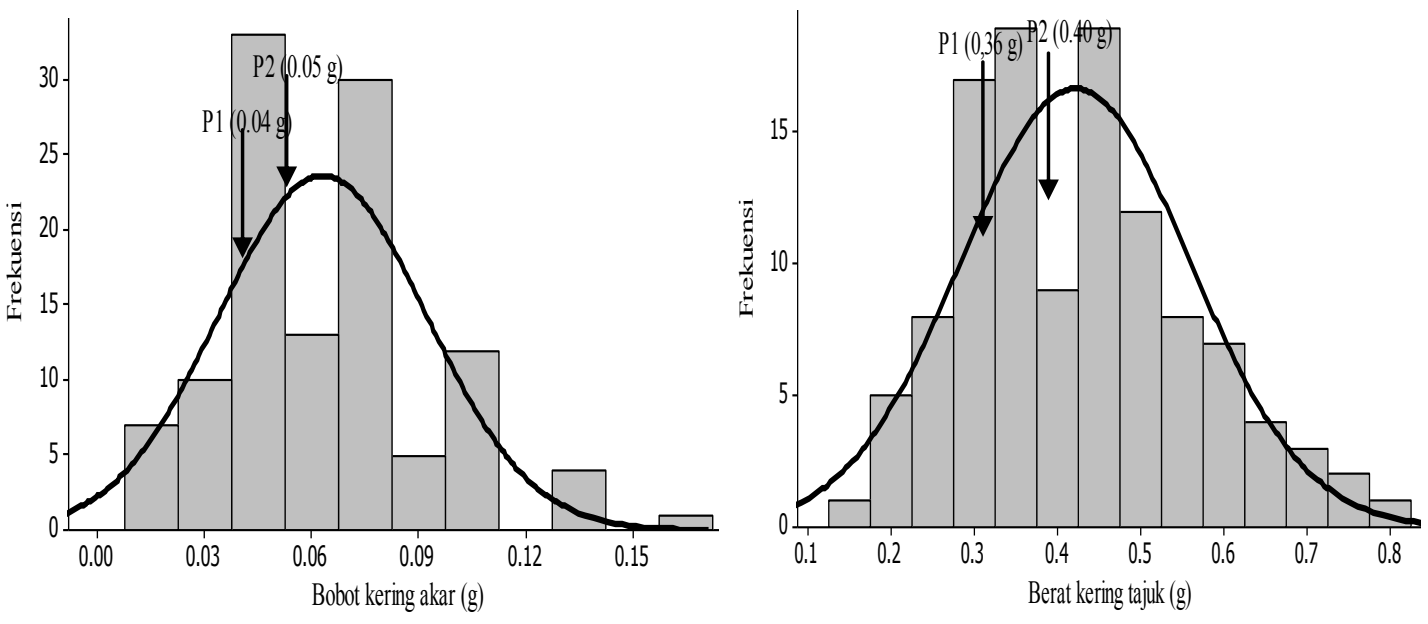

Gambar 2. Sebaran bobot kering akar dan bobot kering tajuk populasi F2 tercekam aluminium pada stadia bibit (14 hari) di kultur hara 

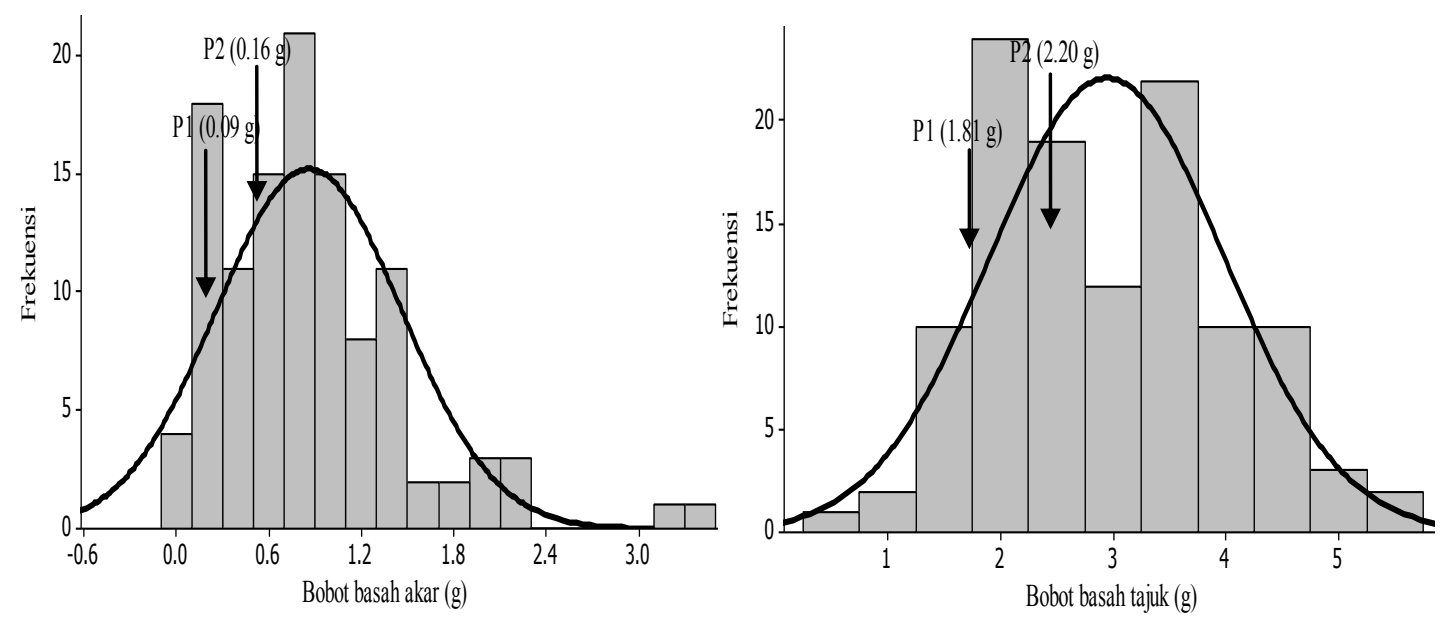

Gambar 3. Sebaran bobot basah akar dan bobot basah tajuk populasi F2 tercekam aluminium pada stadia bibit (14 hari) di kultur hara

kedelai hasil persilangan Tanggamus dan Argomulyo pada kondisi tercekam $\mathrm{Al}$ di kultur hara tidak memiliki sebaran normal yang ditunjukkan oleh nilai skewness yang tidak sama dengan nol (menjulur ke kiri atau ke kanan), hanya karakter panjang akar yang memiliki pola sebaran mendekati normal. Menurut Roy (2000) dan Jayaramachandran et al. (2010), penyebaran karakter kuantitatif pada tanaman yang menjulur ke kiri atau ke kanan menunjukkan adanya pengaruh lingkungan, interaksi genotipe dan lingkungan, pautan gen, dan epistasis. Penyebaran karakter panjang tajuk, nisbah panjang tajuk akar, bobot basah akar, bobot basah tajuk, bobot kering akar, dan bobot kering tajuk yang tidak membentuk sebaran normal terjadi karena keterlibatan gen-gen non aditif dalam mengendalikan keragaman pada populasi F2 atau karena pengaruh lingkungan yang besar dan dikendalikan oleh aksi gen aditif epistasis yang bersifat komplementer (Tabel 2).

Karakter panjang akar memiliki nilai skewness $<0.5$ dan bertanda negatif. Hal ini menunjukkan bahwa karakter panjang akar memiliki sebaran genotipe mendekati normal dan dikendalikan oleh aksi gen aditif dan epistasis duplikat. Menurut Bnejdi et al. (2011) aksi gen yang mengendalikan suatu karakter pada generasi awal sulit dipisahkan dari epistasis duplikat. Epistasis duplikat adalah interaksi

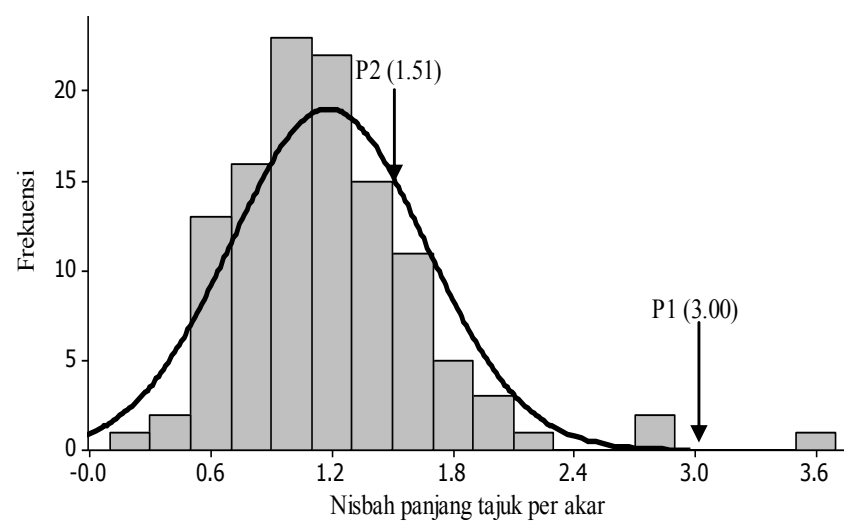

Gambar 4. Sebaran panjang tajuk populasi F2 tercekam aluminium pada stadia bibit (14 hari) di kultur hara epistasis antara gen aditif $\mathrm{x}$ aditif, interaksi antar lokus ini dapat meningkatkan toleransi kedelai terhadap Al pada kondisi tercekam.

Tabel 3 menunjukkan bahwa karakter panjang akar, panjang tunas, dan ratio tunas per akar yang diamati mempunyai nilai heritabilitas arti luas sedang, sedangkan karakter berat basah tunas dan akar serta berat kering tunas dan akar mempunyai nilai heritabilitas arti luas tinggi. Hal ini berarti bahwa karakter-karakter yang diamati tersebut lebih banyak dikendalikan faktor genetik (aksi gen aditif epistasis) dibandingkan faktor lingkungan, dimana ragam genetik terekspresi pada penampilan fenotipik tanaman (Karasu et al., 2009; Bnejdi dan Gazzah, 2010).

Berdasarkan hasil penelitian karakter panjang akar dapat digunakan sebagai karakter seleksi karena karakter ini memiliki nilai heritabilitas sedang dan aksi gen aditif epistasis duplikat. Karakter panjang akar digunakan sebagai karakter seleksi karena karakter panjang akar sangat menentukan tingkat toleransi tanaman terhadap cekaman $\mathrm{Al}$ (Pineros et al., 2005; Ye et al., 2011).

Interaksi antar alel (epistasis) yang lebih penting pada tanaman menyerbuk sendiri, seperti kedelai adalah interaksi aditif $\mathrm{x}$ aditif. Bentuk interaksi ini dapat terfiksasi pada generasi lanjut (Barona et al., 2012). Hal ini berarti pada populasi $\mathrm{F}_{2}$ aksi gen yang terjadi bersifat epistasis aditif $\mathrm{x}$ aditif yang masih belum terfiksasi tetapi diharapkan interaksi gen epistasis pada populasi $\mathrm{F}_{2}$ ini dapat diwariskan ke generasi selanjutnya. Bila seleksi dilakukan pada generasi lanjut $\left(\mathrm{F}_{5}\right)$ diharapkan aksi gen epistasis aditif $\mathrm{x}$ aditif dan aksi gen aditif telah terfiksasi, sehingga pada generasi ini tingkat homozigositasnya telah tinggi ( \pm 95\%) (Riaz dan Chowdhry, 2003; Santoso, 2007).

Seleksi untuk toleransi terhadap cekaman aluminium di kultur hara dapat dilakukan dengan karakter panjang akar karena karakter ini dikendalikan oleh aksi gen aditif epistasis dengan nilai heritabilitas sedang (Tabel 2 dan 3). Oleh karena itu metode yang sesuai adalah metode SSD (Single Seed Descent) karena jumlah genotipe yang digunakan sedikit dengan ragam yang luas. Menurut Lalic et al. (2003) metode SSD efektif digunakan untuk meningkatkan keragaman fenotipe. 
Tabel 2. Nilai skewness, aksi gen, nilai kurtosis, dan bentuk grafik sebaran genotipe F2 hasil persilangan kedelai varietas Argomulyo dan Tanggamus pada cekaman aluminium di kultur hara

\begin{tabular}{lclcl}
\hline Karakter & Skewness & \multicolumn{1}{c}{ Aksi gen } & Kurtosis & Keterangan \\
\hline Panjang akar & -0.73 & Aditif + epistasis duplikat & 0.8 & Dikendalikan banyak gen \\
Panjang tajuk & 1.55 & Aditif + epistasis komplementer & 7.34 & Dikendalikan sedikit gen \\
Bobot basah akar & 1.3 & Aditif + epistasis komplementer & 2.77 & Dikendalikan banyak gen \\
Bobot basah tajuk & 0.22 & Aditif + epistasis komplementer & -0.49 & Dikendalikan banyak gen \\
Bobot kering akar & 0.76 & Aditif + epistasis komplementer & 0.98 & Dikendalikan banyak gen \\
Bobot kering tajuk & 0.44 & Aditif + epistasis komplementer & -0.35 & Dikendalikan banyak gen \\
Nisbah panjang tajuk akar & 1.71 & Aditif + epistasis komplementer & 5.58 & Dikendalikan sedikit gen \\
\hline
\end{tabular}

Tabel 3. Nilai pendugaan komponen ragam dan heritabilitas arti luas populasi F2 pada cekaman aluminium di kultur hara

\begin{tabular}{lccccc}
\hline Karakter & $\sigma^{2} \mathrm{p}$ & $\sigma^{2} \mathrm{e}$ & $\sigma^{2} \mathrm{~g}$ & $\mathrm{~h}^{2} \mathrm{bs}$ & Kriteria \\
\hline Panjang akar & 64.37 & 50.15 & 14.23 & 22.0 & sedang \\
Panjang tajuk & 192.08 & 175.12 & 16.96 & 26.34 & sedang \\
Bobot basah akar & 0.36 & 0.03 & 0.34 & 92.7 & tinggi \\
Bobot basah tajuk & 1.08 & 0.24 & 0.84 & 77.85 & tinggi \\
Bobot kering akar & 0.001 & 0.000 & 0.001 & 54.39 & tinggi \\
Bobot kering tajuk & 0.019 & 0.009 & 0.010 & 50.75 & tinggi \\
Nisbah panjang tajuk/akar & 0.23 & 0.19 & 0.05 & 20.71 & sedang \\
\hline
\end{tabular}

Keterangan: $\sigma^{2} \mathrm{p}=$ ragam fenotipe; $\sigma^{2} \mathrm{~g}=$ ragam genetik; $\sigma^{2} \mathrm{e}=$ ragam lingkungan; $\mathrm{h}^{2} \mathrm{bs}=$ nilai heritabilitas arti luas

\section{KESIMPULAN}

Karakter panjang akar, panjang tajuk, nisbah panjang tajuk akar, bobot basah akar, bobot basah tajuk, bobot kering akar dan bobot kering tajuk dari populasi $\mathrm{F}_{2}$ mempunyai nilai tengah yang melebihi kedua tetuanya dengan nilai heritabilitas arti luas dari sedang hingga tinggi. Aksi gen aditif epistasis duplikat hanya terjadi pada karakter panjang akar sedangkan karakter panjang tajuk, panjang tajuk, nisbah panjang tajuk akar, bobot basah akar, bobot basah tajuk, bobot kering akar dan bobot kering tajuk diatur oleh aksi gen epistasis komplementer. Semua karakter yang diamati memiliki pola sebaran yang bersifat kontinu dan menunjukkan bahwa semua karakter tersebut dikendalikan oleh banyak gen.

\section{DAFTAR PUSTAKA}

Adie, M., A. Krisnawati. 2007. Biologi tanaman kedelai. hal. 45-73. Dalam Sumarno, Suyamto, A. Widjono, Hermanto, H. Kasim (Eds.). Kedelai. Badan Penelitian dan Pengembangan Pertanian, Pusat Penelitian dan Pengembangan Tanaman Pangan, Bogor.

Arsyad, D.M., M.M. Adie, H. Kuswantoro. 2007. Perakitan varietas unggul kedelai spesifik agroekologi. hal. 205-228. Dalam Sumarno, Suyamto, A. Widjono,
Hermanto, H. Kasim (Eds.). Kedelai. Badan Penelitian dan Pengembangan Pertanian, Pusat Penelitian dan Pengembangan Tanaman Pangan, Bogor.

Barona, M.A.A., J.M.C. Filho, V.S. Santos, I. O. Geraldi. 2012. Epistatic effect on grain yeild of soybean [Glycine max (L.) Merrill]. Crop Breeding and Applied Biotechnology. Braz. Soc. Plant Breed. 12:231-236.

Bnejdi, F., M. El Gazzah. 2010. Epistasis and genotype-byenvironment interaction of grain yield related traits in durum wheat. J. Plant Breed Crop. Sci. 2:24-29.

Bnejdi, F., C. Hanbary, E.G. Mohamed. 2011. Genetic adaptability of inheritance of resistance to biotic and abiotic stress level on crop: Role of epistasis. Afric. J. Biotech. 10:19913-19917.

Caniato, F.F., C.T. Guimaraes, R.E. Schaffert, V.M.C. Alves, L.V. Kochian, A. Borem, P.E. Klein, J.V. Magalhaes. 2007. Genetic diversity for aluminum tolerance in sorghum. Theor. Appl. Genet. 114:863-876.

[Deptan] Departemen Pertanian. 2012. Kebutuhan dan status pemanfaatan varietas. http://www.deptan.go.id. [16 Januari 2014]. 
Ginting, E., S.S. Arlina, S. Widowati. 2009. Varietas unggul kedelai untuk bahan baku industri pangan. J. Litbang Pertanian 28:79-87.

Jayaramachandran, M., N. Kumaravadivel, S. Eapen, G. Kandasamy. 2010. Gene action for yield attributing characters in segregating generation (M2) of sorghum (Sorghum bicolor L.). Elec. J. Plant Breeding 1:802808 .

Karasu, A., M. Oz, A.T. Goksoy, Z.M. Turan. 2009. Genotype by environment interaction, stability and heritability of seed yield and certain agronomical traits in soybean [Glycine max (L.) Merr.]. Afric. J. Biotech. 8:580-590.

Kuswantoro, H., N. Basuki, D.M. Arsyad. 2011. Inheritance of soybean pod number trait on acid soil. Agrivita 33:119-126.

Lalic, A., J. Kovacevic, D. Novoselovic, G. Dresner, D. Babic. 2003. Comparison of pedigree and single seed descent method (SSD) in early generation of barley. Braz. Plant Breeding 1:1-6.

Mangoendidjojo, W. 2003. Dasar-Dasar Pemuliaan Tanaman. Penerbit Kanisius, Yogyakarta.

Maron, L.G., M. Kirst, C. Mao, M.J. Milner, M. Menossi, L.V. Kochian. 2008. Transcriptional profiling of aluminum toxicity and tolerance responses in maize roots. New Phyt. 179:116-120.

Mulyani, A., S. Ritung, I. Las. 2011. Potensi dan ketersediaan sumberdaya lahan untuk mendukung ketahanan pangan. J. Litbang Pertanian 30:73-80.

Ohki, K. 1987. Aluminum stress on sorghum growth and nutrient relationships. Plant and Soil 98:195-202.
Ojo, G.O.S., S.A. Ayuba. 2012. Determination of appropriate level(s) of aluminum activity for the screening of tropically adapted soybean genotypes in sand culture. Afr. J. Agric. Res. 7:4607-4612.

Phillips, P.C. 2008. Epistasis, the essential role of gene interactions in the structure and evolution of genetic systems. Nat. Rev. 9:855-867.

Pineros, M.A., J.E. Shaff, H.S. Manslank, V.M.C. Alves, L.V. Kochian. 2005. Aluminum resistance in maize cannot be solely explained by root organic acid exudation. A comparative physiological study. Plant Physiol. 137:231-241.

Riaz, R., M. Chowdhry. 2003. Estimation of variation and heritability of some physio-morphic traits of wheat under drought conditions. Asian J. Plant Sci. 2:748755 .

Roy, D. 2000. Plant Breeding: Analysis and Exploitation of Variation. Narosa, New Delhi.

Santoso, J. 2007. Tindak gen ketahanan terhadap penyakit karat (Pucinnia arachidis, Speg.) pada kacang tanah. J. Ilmu-Ilmu Pertanian Indonesia 9:172-177.

Silva, S., O.P. Carnide, P.M. Lopes, M. Matos, H.G. Pinto, C. Santos. 2012. Zonal responses of sensitive vs tolerant wheat roots during $\mathrm{Al}$ exposure and recovery. J. Plant Physiol. 169:760-769.

Supijatno, D. Sopandie, M. Jusuf, S. Harran. 1995. Fisiologi daya adaptasi kedelai [Glycine $\max$ (L.) Merr] terhadap cekaman $\mathrm{pH}$ rendah dengan aluminium tinggi. Bul. Agron. 23:8-16.

Ye, Y., W. Qiaolan, G. Mingjian, G. Zaihua, Z. Zhuqing. 2011. Al-induced root cell wall chemical components differences of wheat (Triticum aestivum L.) differing in Al tolerance. Afr. J. Agric. Res. 10:6762-6772. 